\title{
Organic pollutants removal from oilfield produced water using nano magnetite as adsorbent
}

\author{
Naser G.F.*, Dakhil I.H., and Hasan A.A. \\ ${ }^{1}$ Chem. Eng. Dep., Faculty of Engineering, Al Muthanna University, Iraq \\ Received: 16/07/2021, Accepted: 26/09/2021, Available online: 04/10/2021 \\ *to whom all correspondence should be addressed: e-mail: ghazi_faisal@mu.edu.iq \\ https://doi.org/10.30955/gnj.003875
}

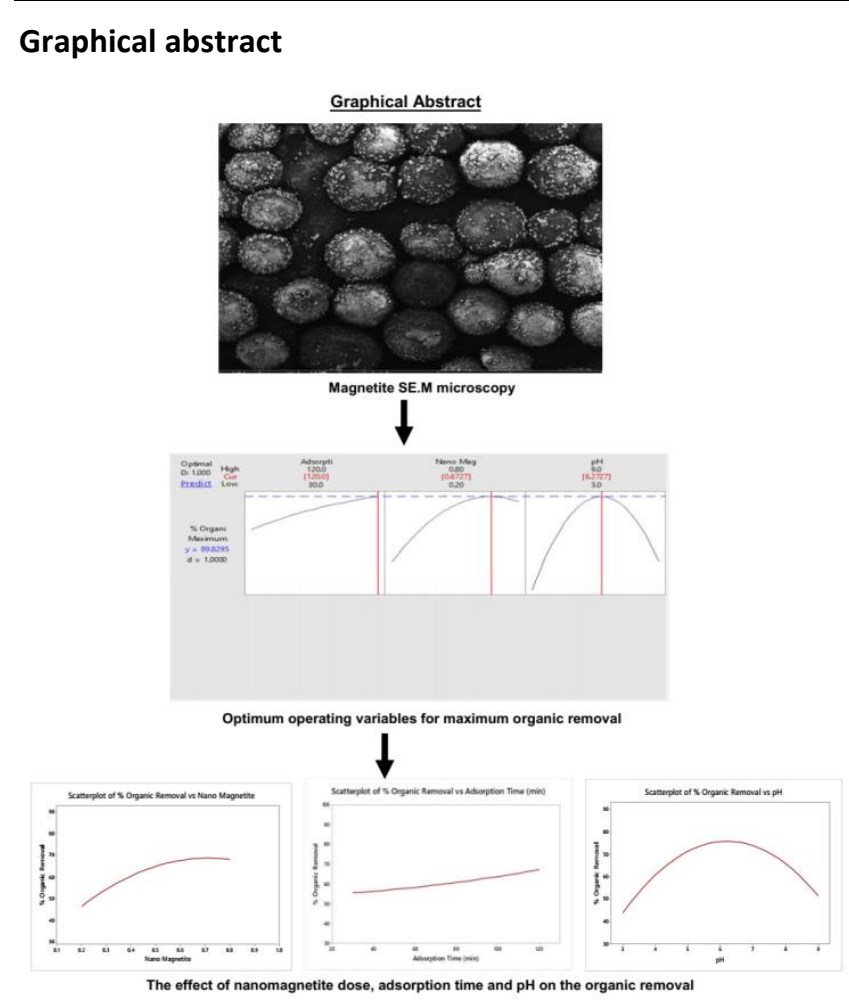

Abstract

The current study investigates the ability of Nano magnetite as an adsorbent to remove organic materials from oilfield-produced water (PW). The effect of several variables on the removal procedure was investigated, such as nano magnetite dose, $\mathrm{pH}$ of solution and adsorption period. The adsorbent was carefully examined and completed using several approaches FTIR, SEM and surface area analyzer. The results show that the best organic removal reached more than $89 \%$ at $0.7 \mathrm{~g}$ Nano magnetite dose in $120 \mathrm{~min}$ through $\mathrm{pH}=6.0$ at room temperature. Three mathematical isotherm models of adsorption were used in this study: Langmuir, Freundlich and BrunauerEmmett-Teller. It seems that the Langmuir model and Brunauer-Emmett-Teller was best fitted model over the experimental variety with a correlation coefficient of 0.994 and 0.995 respectively.

Keywords: Produced Water; adsorbents; nano magnetite; dose; RSM; isotherms.

\section{Introduction}

For many countries, oil is the primary source of wealth and energy (Igunnu and Chen, 2012). The oil and gas manufacturing regular growths include a vast quantity of injected water toward the oil recovery that remains active toward the surface lengthways with organic compounds, salt, and extra solutes and remains frequently known by way of "produced water" (Rashid et al., 2020). Oil trades produced wastewater is real multifaceted, and comprises many organic and inorganic substances, such as free and dissolved oil, phenol and heavy metal through products (AlJaberi et al., 2020). For the reason that the wastes of oilfields cause ecological contaminations, treatment remains vital beforehand elimination. The action of these wastes will maybe consequence in improved oil retrieval, oil/water separation, recycling of water, defense of downstream facilities, and finally follows health and environmental safety guidelines (Hassan and Mousa Alzobai, 2019). The treatment of wastewater goals remains toward recover the organic content and edge the previous waste aimed at recycling or reject. The wastewaters are gutted through numerous physical and chemical incomes beforehand the release and rules place severe limits on stages of contaminants which can remain cleared to the sea (Ibrahim et al., 2019). The environment needs the development and implementation of appropriate action services capable of eliminating dangerous toxins from many of these industrial waters. Due to the high level of environmental attention paid to these watercourses, they remain difficult to treat (Ali et al., 2016) and (Alakoul et al., 2021).Organic pollutants and their derivatives have a dangerous effect on human life for a long time, so it needs special processing not depends on traditional methods only (Ali et al., 2018).Numerous modern treatments has been applied to remove the organic content from produced water: Advanced oxidation processes (Naeem et al., 2018) and (Al-zobai et al., 2020), coagulation -adsorption (Rosenblum et al., 2016), Electro-oxidation (Ahmed et al., 2021; Alturki et al., 2021), Electrocoagulation (Manilal et al., 2020) and separation of a membrane (Zsirai et al., 2018). Amongst these approaches, the treatment of adsorption gained a high effect of the most attractive in terms of financial and ecological friendly (Ibrahim et al., 
2010). Nevertheless, whenever the wastewater watercourses are sufficient, such treatments request great costs. Adsorption remains one of the organic elimination approaches that had learned cumulative thought through the asset of its possible efficiency and its extra advantages similar being refillable, high selectivity at molecular level, cheap by way of per energy demands, flexibility in dealing with numerous substances, protection towards poisonous constituents and comfort of handling (Naeem and Hassan, 2018). Adsorption keeps its place generally by considering it a way of one of the most extensive approaches aimed at eliminating pollutants from wastewater solutions. Profitable activated carbon has been deliberate by way of an adsorbent for the elimination of contaminants from waters for several years because of the great exact surface area and pore structure. To overwhelm this drawback, substantial care has remained given toward make activated carbons resulting from self obtainable and squat cost waste materials (Depci et al., 2012). The good-looking property of iron oxide nanoparticles authorizes informal disseverment of adsorbents from the outline and might remain recycled for the additional request (Namdeo, 2018). Furthermore, as a cost-effective and environmentally friendly material, magnetite has high adsorption capabilities for a wide range of species, including dissolved metals, particulate matter, organic and biological components. (Petrova et al., 2011). The purpose of this work is to select the perfect PW activity by utilizing the nano magnetite as an adsorbent. The Nanomagnetite dosage in addition to the $\mathrm{pH}$ is principal effects to affect the general action capability and these were thoughtful in this work and study the kinetic model for adsorption processes.

\section{Materials and methods}

\subsection{Produced water}

Samples of produced water (PW) were collected as from AlAhdab oil field at Wassit governorate, Iraq. The properties of wastewater and other constituent's in this PW was registered in Tables 1 and 2 respectively:

Table 1. Properties of wastewater

\begin{tabular}{cc}
\hline Property & Concentration \\
\hline Organic content & $103.5 \mathrm{ppm}$ \\
\hline $\mathrm{pH}$ & 6.77 \\
\hline TDS & $137800 \mathrm{ppm}$ \\
\hline Conductivity & $170.5 \mathrm{~ms} \mathrm{~cm}^{-1}$ \\
\hline Turbidity & $84 \mathrm{NTU}$ \\
\hline TSS & $20.25 \mathrm{ppm}$ \\
\hline
\end{tabular}

Table 2. Constituents of produced water

\begin{tabular}{cc}
\hline Constituent & Concentration (ppm) \\
\hline Calcium & 7835 \\
\hline Magnesium & 2335 \\
\hline $\mathrm{HCO}_{3}$ & 258 \\
\hline Dissolved oxygen content & 0.063 \\
\hline Manganese & 3 \\
\hline
\end{tabular}

2.2. Nano magnetite characterization

A type of microscopy that uses electrons to (SEM) inspection was attained to examine the adsorbent's morphology. In this research, JSM-6100 was used to analyze the nanomagnetite before adsorption. (FT-IR) utilized for identifying surface useful collections of FT-IR spectroscope (Bruker), wherever a range from 4000 to 500 $\mathrm{cm}^{-1}$.

\subsection{Materials}

Nano Magnetite adsorbent made of Merck, Sodium chloride, $\mathrm{CCL}_{4}$, hydrochloric acid in addition Sodium hydroxide both made of Merck-India, distilled water, adjust the $\mathrm{pH}$ of the solution with $\mathrm{HCL} 1 \mathrm{~N}$ or $\mathrm{NaOH} 1 \mathrm{~N}$.

\subsection{Adsorption procedure}

All procedures of adsorption experiments were achieved at the volume of nano magnetite with 150 milliliter PW in a 250-milliliter glass bottle. The adsorptions speed at a value of two hundred revolutions per minute through shaking device at room temperature with $\mathrm{pH}$ (3-9). The significance of adsorbent amount from 0.2 to $0.8 \mathrm{~g}$ of nano magnetite specific amount of nano magnetite with 103.5 ppm produced water. The $\mathrm{pH}$ ranged from three to nine, and the adsorption time interval from 30 until 120 minutes was controlled by the magnetite particles and dosage. The mass balance for the following equation was being used to evaluate the amount of PW at equilibrium. (Gupta, 2011):

$$
q_{\mathrm{e}}=\mathrm{V}\left(\mathrm{C}^{\circ}-C_{\mathrm{e}}\right) / \mathrm{W}
$$

Wherever $q_{\mathrm{e}}\left(\mathrm{mg} \mathrm{g}^{-1}\right)$ : represents the organic content in PW per unit of adsorbent mass at known volume, time and magnetite mass, $\mathrm{W}(\mathrm{g})$ : acts the magnetite weight, while symbols $C^{\circ}, C_{\mathrm{e}}$ (ppm): exemplify initial concentration, final concentration of produced water at time $t$ respectively. The organic removal efficiency by nano magnetite was calculated by the following equation:

$$
\text { Adsorption }(\%)=\left(C^{\circ}-C_{e} / C^{\circ}\right)
$$

\subsection{Experimental design}

PW mineralization by the nano magnetite execution is better by using the technique of Central -Composite Design (CCD) under Response Surface Methodology as software of experimental design, data analysis and scheme charting. The factors, such as time adsorption $\left(X_{1}\right)$, the dosage of magnetite $\left(\mathrm{X}_{2}\right)$ and $\mathrm{pH}\left(\mathrm{X}_{3}\right)$, were coded in the CCD with their different grades, such as time adsorption $\left(X_{1}\right)$ from half-hour to two hours, a dosage of magnetite $\left(X_{2}\right)$ from 0.2 until 0.8 and $\mathrm{pH}\left(\mathrm{X}_{3}\right)$ from 3 to 9 .

\subsection{Organic concentration determination by UV- spectrophotometer analysis}

$0.2 \mathrm{gm}$ of sodium chloride was added to fifty $\mathrm{mL}$ PW by using a funnel, $5 \mathrm{ml}$ of $\mathrm{CCL}_{4}$ was added and shaking for 2 minutes. After $25 \mathrm{~min}$., the wastewater was separated into two special layers, the lower organic layer especially used for the absorbance measurement, and organic content was computed using the calibration curve. The turbidity was monitored and read using a turbid meter (Lovi-bond, SN 10/1471) (Ernestina Elizabeth Banda-Cruz et al., 2016). 


\section{Results and discussions}

\subsection{Description of biosorbent}

\subsubsection{FT-IR Examination}

FT-IR spectra at a range of $(4000-500) \mathrm{cm}^{-1}$ for nano magnetite were exposed in Figure 1. FTIR test documented the being harmfully charged functional hydroxyl groups, carboxyl group, in addition amine group at the nano magnetite's surface. Because of hydroxyl group expansion or amine $\left({ }^{-} \mathrm{NH}_{2}\right)$ bending of polymeric compounds, the entire band at 3317.67 powder stays attributed. The strength of the $\left({ }^{-} \mathrm{CH}_{2}\right)$ corresponding spreading vibrations remains in the range shown in Figure 1.

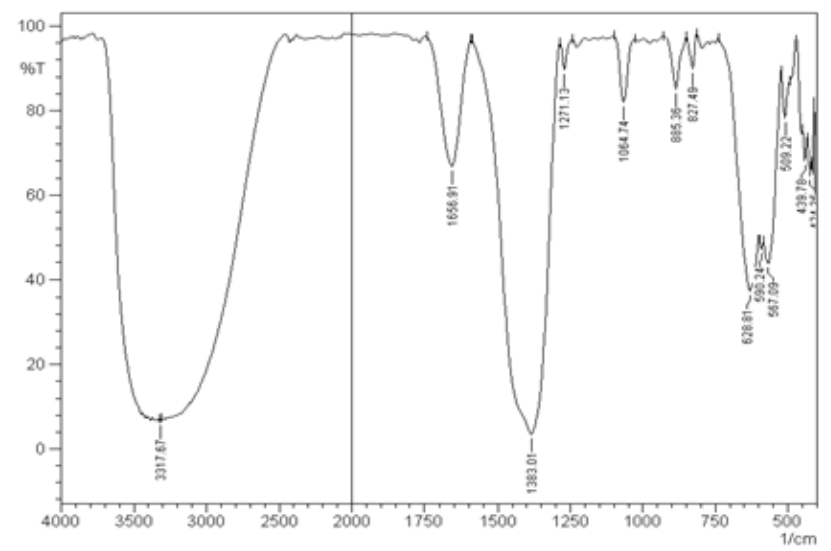

Figure 1. FT-IR testing of Nanomagnetite.

\subsubsection{SE.M examination/specific surface area}

Entire surface and shape of the adsorbent are explained by the SEM image. The surface morphology of nano magnetite was properly produced into a filamentous pattern Figure 2. It has a porous and irregular construction with a vast number of pores that could still operate as adsorbing zones, making it significant. This property distinguishes Table 3. Careful variables significances nano magnetite's surface as a good adsorbent for removing organic content. The nano magnetite has a surface area of about $98.11 \mathrm{~m}^{2} \mathrm{~g}^{-1}$.

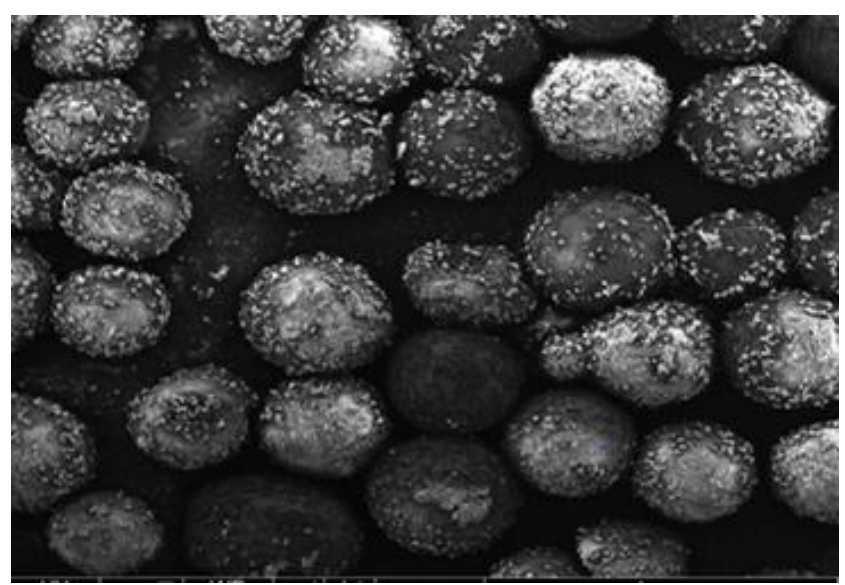

Figure 2. Magnetite SE.M microscopy.

\subsection{Regression models}

The responses and independent variables might be studied at least-squares technique by a 2 nd. order model by (Davarnejad et al., 2014):

$$
Y=B_{0}+\sum_{i=1}^{q} B_{i} X_{i}+\sum_{i=1}^{q} B_{i i} X_{i}^{2}+\sum_{i} \sum_{j} B_{i j} X_{i} X_{j}+\varepsilon
$$

Wherever a symbol $y$ acts the elimination responses, while $X_{1}, X_{2}, \ldots X q$ symbolize the employed variables. The constant of regression is referred to as Bo, while the linear regression constant is referred to as $\mathrm{Bi}$. However, Bii acts the squared regression constant and $\mathrm{Bij}$ acts the crossproduct reversion constant, so the error is symbolized by a symbol $\varepsilon$. Table 3 displays the result of the variables used in the study based on CCD design, as well as the percentage of organic elimination in PW.

\begin{tabular}{|c|c|c|c|c|c|c|c|c|}
\hline Run & StdOrder & Run Order & Pt Type & Blocks & $\begin{array}{c}X_{1}: \text { Adsorption } \\
\text { time (min.) }\end{array}$ & $\begin{array}{c}X_{2}: \text { Nanomagnetite } \\
\text { dose }(\mathrm{g})\end{array}$ & $X_{3}: \mathrm{pH}$ & $\begin{array}{c}\text { Organic } \\
\text { removal\% }\end{array}$ \\
\hline 1 & 1 & 1 & 2 & 1 & 30 & 0.2 & 6 & 52.36 \\
\hline 2 & 2 & 2 & 2 & 1 & 120 & 0.2 & 6 & 63.45 \\
\hline 3 & 3 & 3 & 2 & 1 & 30 & 0.8 & 6 & 77.96 \\
\hline 4 & 4 & 4 & 2 & 1 & 120 & 0.8 & 6 & 89.66 \\
\hline 5 & 5 & 5 & 2 & 1 & 30 & 0.5 & 3 & 40.32 \\
\hline 6 & 6 & 6 & 2 & 1 & 120 & 0.5 & 3 & 51.32 \\
\hline 7 & 7 & 7 & 2 & 1 & 30 & 0.5 & 9 & 51.36 \\
\hline 8 & 8 & 8 & 2 & 1 & 120 & 0.5 & 9 & 64.58 \\
\hline 9 & 9 & 9 & 2 & 1 & 75 & 0.2 & 3 & 35.21 \\
\hline 10 & 10 & 10 & 2 & 1 & 75 & 0.8 & 3 & 48.96 \\
\hline 11 & 11 & 11 & 2 & 1 & 75 & 0.2 & 9 & 34.66 \\
\hline 12 & 12 & 12 & 2 & 1 & 75 & 0.8 & 9 & 55.36 \\
\hline 13 & 13 & 13 & 2 & 1 & 75 & 0.5 & 6 & 82.31 \\
\hline 14 & 14 & 14 & 2 & 1 & 75 & 0.5 & 6 & 81.99 \\
\hline 15 & 15 & 15 & 2 & 1 & 75 & 0.5 & 6 & 82.05 \\
\hline
\end{tabular}

The mathematical formula (Equation 4) explain terms of actual factors as a real values connecting the organic 
elimination response to the operating variables reveals the linkages between these variables, based on untried consequences:

$$
\begin{aligned}
& \text { Organic Elimination }=-91.5+0.208 X_{1}+132.4 X_{2} \\
& +38.34 X_{3}-0.00072 X_{1}^{2}-108.9 X_{2}^{2}-3.196 X_{3}^{2} \\
& +0.011 X_{1} X_{2}+0.0041 X_{1} X_{3}+1.93 X_{2} X_{3}
\end{aligned}
$$

\subsection{Nano magnetite solution effect}

The organic content adsorption on Nano magnetite as an adsorbent quantity function was showed in Figure 3 . The removal of organic in PW was increased with the cumulative quantity of Nano Magnetite under constant conditions reached $72.3 \%$. As clearly seen in Figure 3, increasing the dose of nanomagnetite has a positive effect by increasing the organic removal from PW.

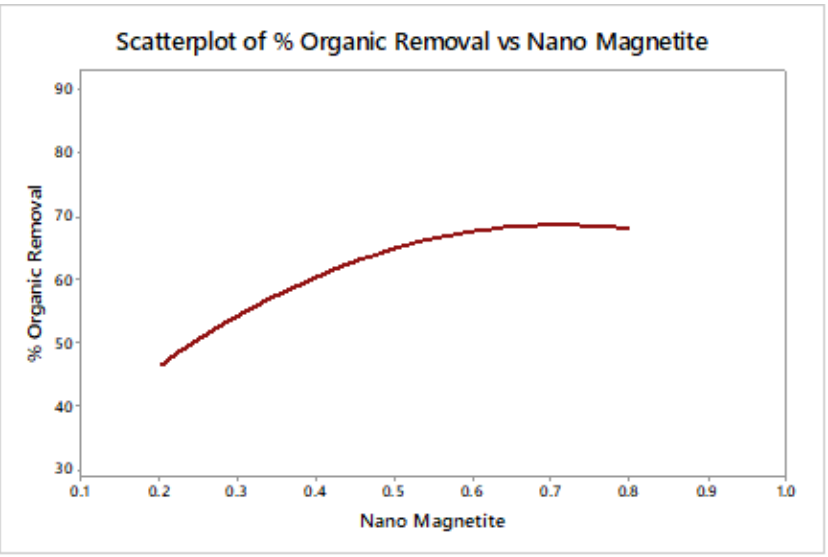

Figure 3. The effect of Nano Magnetite on the organic removal ( $\mathrm{pH}=6$, time $120 \mathrm{~min}$ ).

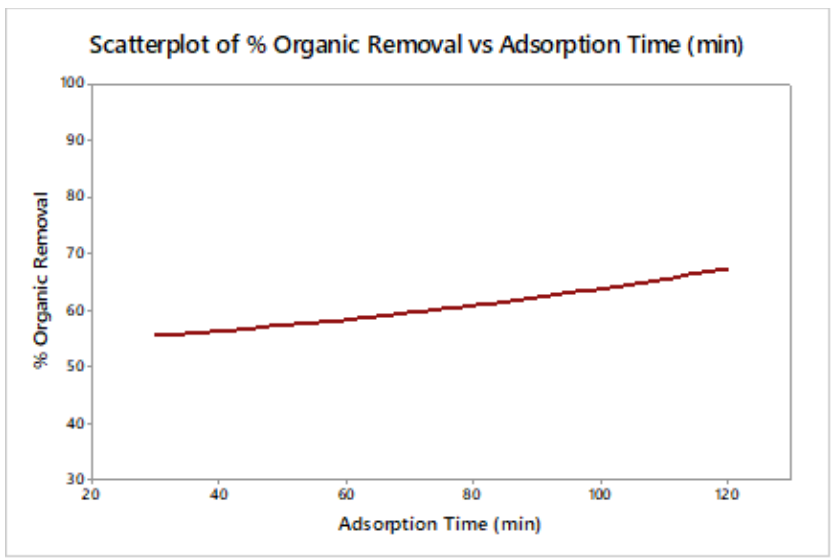

Figure 4. The effect of adsorption time on the organic removal (Nano magnetite dose $=0.7 \mathrm{~g}, \mathrm{pH}=6$ ).

\subsection{Adsorption time effect}

To develop adsorption studies, it is important to investigate the effect of adsorption duration upon on adsorption treatment. (Jafer et al., 2019). The trials are organic that adsorption time differs from the first thirty minutes to the end of 120 minutes at a various amount Nanomagnetite dose between (0.2) and (0.8) g. Adsorption treatments persist, so the adsorption equilibrium can be achieved within 90 minutes, as shown in Figure 4. Extra increases in the adsorption period do not recover the adsorption activity. The singularity might remain temporarily, first, all vigorous positions above the surface of the adsorbent remain free and the concentration of organic remains rising. Later that duration, insufficient surface vigorous locations remain available, so only a sharp low increase in organic uptake remains experiential (Hassan et al., 2020). Consequently, the finest adsorption time for organic content in produced water was specified of two hours preparing for all the cases.

\section{5. $\mathrm{pH}$ solution effect}

The $\mathrm{pH}$ of the $\mathrm{PW}$ in which the adsorption process was a significant limit in the treatment. The degree of electrostatic customers associated with ionized contaminants and the functional groups above the surface of nanomagnetite stay chiefly an important role of final $\mathrm{pH}$ (Ofomaja et al., 2009). For pH interval 3-9, sorption of both divalent organic content was considerably little, while the initial value of $\mathrm{pH}$ increased, organic content uptake increased as shown in Figure 5. It is clear that the best organic removal happened at the interval $\mathrm{pH}$ between (5) and (7). To avoid probable hydroxide deposition, high levels of $(\mathrm{pH})$ are being used. (El-Shafey, 2010). These points can be further clarified by the fact that the surface charge of the biomass stays positive at lower levels of $\mathrm{pH}$, which is unfavorable for cationic bio_sorption. Furthermore, at the active sites, hydrogen ions interact intensely with organic content, as well as the conflicting effect of hydrogen ions, decreases as $\mathrm{pH}$ rises (Feng et al., 2009).

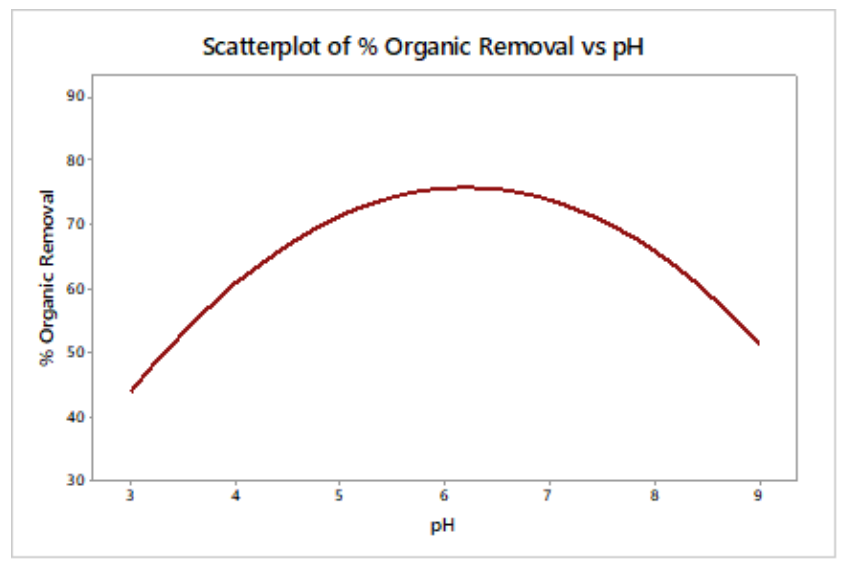

Figure 5. The $\mathrm{pH}$ effect on the organic removal (Nano magnetite dose $=0.7$, time $=120 \mathrm{~min}$ ).

\subsection{Enhancing the employed variables}

From the previous studies, it is obvious that can explore the optimum conditions by selecting the minimum and maximum values. Minitab-17 was also used to obtain premium values for the variables used, such as adsorption period, Nanomagnetite dosage, and $\mathrm{pH}$. The quantitative consequences of the D-optimization are labeled in Figure 6. The highest organic content elimination abilities were greater than 89 percent. 


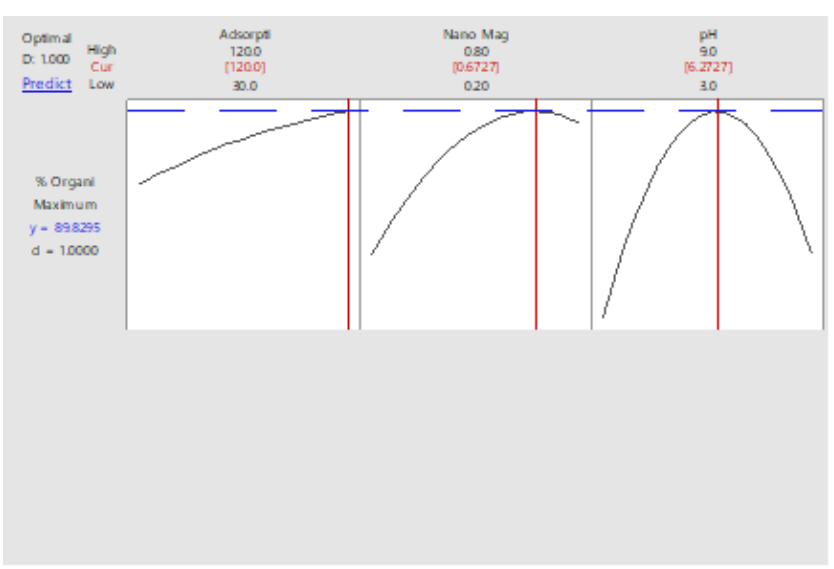

Figure 6. Optimum operating variables for maximum organic removal.

Two confirmation experiments has been conducted the optimum operating conditions as shown in Table 4:

Table 4. Confirmation experiments

\begin{tabular}{ccccc}
\hline Run & Time & pH & Nano magnetite & Removal\% \\
\hline 1 & 120 & 6 & 0.7 & 86 \\
\hline 2 & 120 & 6 & 0.7 & 92 \\
\hline
\end{tabular}

\subsection{Adsorption Isotherms}

As a result of the adsorption process, there are some implications that were agreed to equations of Langmuir, Freundlich and Brunauer-Emmett-Teller (BET) (Figures 7-9) contrasting mathematical isotherm equations for Nanomagnetite adsorbent. Isothermal limitations were computed from the modification of each adsorption isotherm in order to choose the best model shadowed by untested bio-sorption test results. (Dakhil, 2020) and (Naser et al., 2021). The working conditions must be carefully considered for the contrast of the data, as the setup isothermal experimental effects are dependent on them. (Rangabhashiyam and Selvaraju, 2015). The Langmuir model and BET appear to best fit the experimental results over the experimental range with reasonable correlation values $\left(R^{2}>0.99\right)$. This attitude is similar to the interpretations given in the (Pereira et al., 2010; Mukhtar et al., 2020; Dakhil and Ali, 2021). The equations of Langmuir, Freundlich and Brunauer-EmmettTeller can be written respectively as:

$$
1 / q_{\mathrm{e}}=1 / q_{\mathrm{m}}+\left(1 / K_{\mathrm{L}} q_{\mathrm{m}}\right)\left(1 / C_{e}\right)
$$

Where: $\left(q_{\mathrm{e}}\right)$ acts adsorption capacity $\left(\mathrm{mg} \mathrm{g}^{-1}\right),\left(C_{e}\right)$ indicates to the equilibrium concentration $\left(\mathrm{mg} \mathrm{L}^{-1}\right),\left(K_{\mathrm{L}}\right)$ acts Langmuir constant $\left(\mathrm{L} \mathrm{mg}^{-1}\right)$, so $\left(q_{\mathrm{m}}\right)$ acts the maximum capacity $\left(\mathrm{mg} \mathrm{g}^{-1}\right)$ (Xu et al., 2013).

$$
\log \left(q_{\mathrm{e}}\right)=\log K_{\mathrm{f}}+(1 / n) \log \left(C_{\mathrm{e}}\right)
$$

Where $K_{\mathrm{f}}$ : acts the Freundlich constant isotherm model and $n$ : represents linearity adsorption constant (Ramachandran et al., 2011).

$$
C_{\mathrm{e}} /\left(C^{\circ}-C_{e}\right) q_{\mathrm{m}}=\left[\left(K_{\mathrm{B}}-1\right) / K_{\mathrm{B}} q_{\mathrm{m}}\right]\left[C_{\mathrm{e}} / C^{\circ}\right]+1 / K_{\mathrm{B}} q_{\mathrm{m}}
$$

Where $q_{m}$ : symbolize maximum ability $\left(\mathrm{mg} \mathrm{g}^{-1}\right), C_{0}$ :acts the adsorbate initial concentration $\left(\mathrm{mg} \mathrm{L}^{-1}\right)$ and $K_{\mathrm{B}}$ : acts the BET constant isotherm model (Mousa and Taha, 2015).

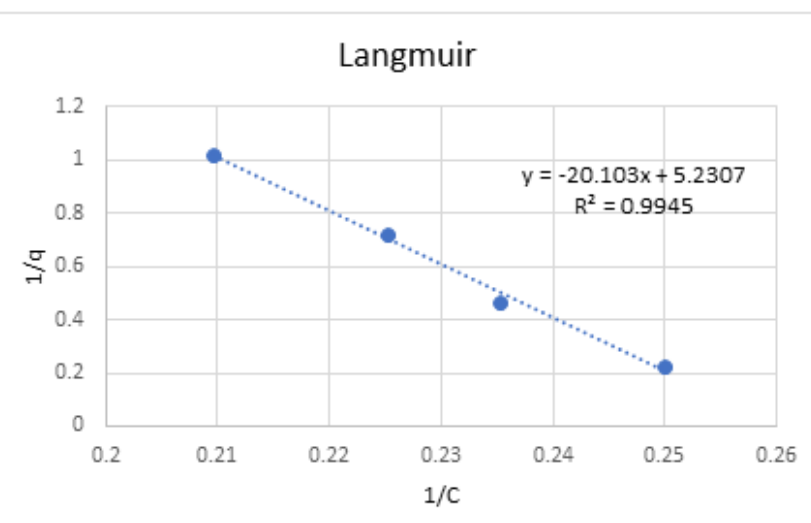

Figure 7. Langmuir isotherm plot for adsorption of organic content on PW.

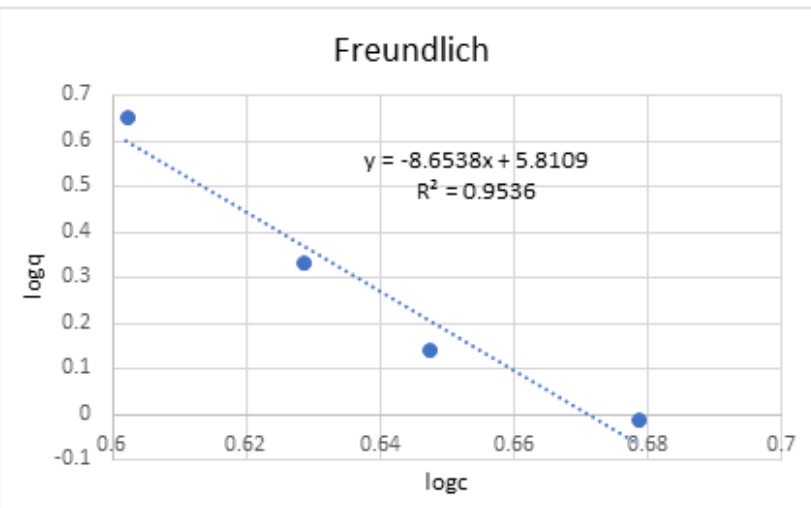

Figure 8. Freundlich isotherm plot for adsorption of organic content on PW.

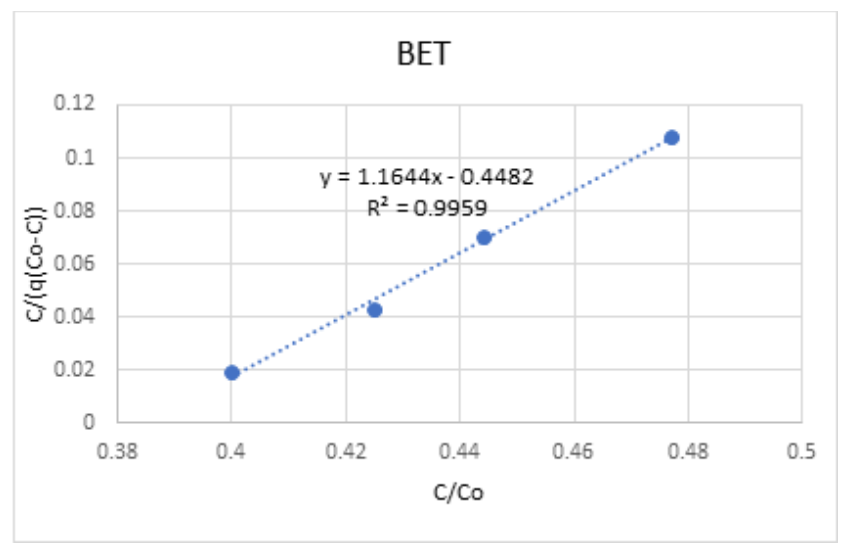

Figure 9. BET isotherm plot for adsorption of organic content on PW.

\section{Conclusions}

The ability of Nano magnetite as an active and low-cost bio sorbent to remove organic materials from PW was discussed in this study. Adsorption limits computed from the Langmuir, Freundlich, and BET isotherms are useful for understanding the mechanisms of the adsorption process and the equilibrium results were found to fit with the Langmuir and BET model. Response surface methodology (RSM) was used to construct the tests, and the data were then regression investigated and modified to find the best 
operating parameter. It was discovered that the maximum removal efficiency more than $89 \%$ at $\mathrm{pH}=6.0$ and $0.7 \mathrm{~g}$ of Nanomagnetite dose in two hours .

\section{Acknowledgment}

The authors are many grateful for the technical assistance supported by the College of Engineering - Chemical Engineering Department at Al Muthanna University in Iraq.

\section{References}

Ahmed H.A., Naser G.F. and Alkaim A.F. (2018). Treatment of textile industries wastewater by advance oxidation process, Journal of Engineering and Applied Sciences, 13(5), 1042-1045.

Ahmed H.A., Naser G.F. and Mohammed S.A. (2016). Photocatalytic degradation of methyl orange dye using different photocatalysts under solar light, International Journal of ChemTech Research, 9(10), 157-165.

Alakoul K.A., Atiyah A.S., Azeez M.Z. and Hassan A.A. (2021), Photovoltaic cell electro-oxidation for oil removal in oil field produced $\mathrm{H}_{2} \mathrm{O}, I O P$ Conference Series: Materials Science and Engineering, 1090, 12072.

AlJaberi F.Y., Abdulmajeed B.A., Hassan A.A. and Ghadban M.L. (2020). Assessment of an electrocoagulation reactor for the removal of oil content and turbidity from real oily wastewater using response surface method, Recent Innovations in Chemical Engineering (Formerly Recent Patents on Chemical Engineering), 13(1), 55-71.

Alturki S.F., Ghareeb A.H., Hadi R.T. and Hassan A.A. (2021). Evaluation of using photovoltaic cell in the electro-fenton oxidation for the removal of oil content in refinery wastewater, IOP Conference Series: Materials Science and Engineering, 1090, 12012.

Al-zobai K.M.M., Hassan A.A. and Kariem N.O. (2020). Removal of amoxicillin from polluted water using $\mathrm{UV} / \mathrm{TiO}_{2}, \mathrm{UV} / \mathrm{ZnO} / \mathrm{TiO}_{2}$, and UV/ZnO, Solid State Technology, 63(3), 3567-3575.

Banda-Cruz E.E., Padrón-Ortega S.I., Gallardo-Rivas N.V., RiveraArmenta J.L., Páramo-García U., Zavala N.P.D. and MendozaMartínez A.M. (2016), Crude oil UV spectroscopy and light scattering characterization, Petroleum Science and Technology, 34(8), 732-738.

Dakhil I.H. and Ali A.H. (2021). Adsorption of methylene blue dye from industrial wastewater using activated carbon prepared from agriculture wastes, Desalination and Water Treatment, 216, 372-378.

Dakhil, I.H. (2020), recycling of agriculture wastes for efficient removal of methyl orange dye using batch adsorption Unit, IOP Conference Series: Materials Science and Engineering, 881(1), 012186.

Davarnejad R., Mohammadi M. and Ismail A.F. (2014). Petrochemical wastewater treatment by electro-Fenton process using aluminum and iron electrodes: Statistical comparison, Journal of Water Process Engineering, 3, 18-25.

Depci T., Kul A.R. and Önal Y. (2012). Competitive adsorption of lead and zinc from aqueous solution on activated carbon prepared from Van apple pulp: Study in single-and multisolute systems, Chemical Engineering Journal, 200, 224-236.

El-Shafey E.I. (2010). Removal of Zn (II) and Hg (II) from aqueous solution on a carbonaceous sorbent chemically prepared from rice husk, Journal of Hazardous Materials, 175(1-3), 319-327.
Feng N.-C., Guo X.-Y. and Liang S. (2009), Kinetic and thermodynamic studies on biosorption of $\mathrm{Cu}$ (II) by chemically modified orange peel, Transactions of Nonferrous Metals Society of China, 19(5), 1365-1370.

Gupta V.K., Gupta B., Rastogi A., Agarwal S. and Nayak A. (2011). A comparative investigation on adsorption performances of mesoporous activated carbon prepared from waste rubber tire and activated carbon for a hazardous azo dye-Acid Blue 113, Journal of Hazardous Materials, 186 (1), 891-901.

Hassan A.A. and Mousa Al-zobai K.M. (2019). Chemical oxidation for oil separation from oilfield produced water under UV irradiation using titanium dioxide as a nano-photocatalyst by batch and continuous techniques, International Journal of Chemical Engineering, 2019.

Hassan A.A., Hadi R.T., Rashid A.H. and Naje A.S. (2020). Chemical modification of castor oil as adsorbent material for oil content removal from oilfield produced water, EM International, 39(4), 892-900.

I.H. Ahmed, A.A. Hassan, and H.K. Sultan. (2021), Study of electrofenton oxidation for the removal of oil content in refinery wastewater, IOP Conference Series: Materials Science and Engineering, 1090, 012005.

Ibrahim M.K., Al-Hassan A.A. and Naje A.S. (2019). Utilisation of Cassia surattensis seeds as natural adsorbent for oil content removal in oilfield produced water, Pertanika Journal of Science \& Technology, 27(4), 2123-2138.

Ibrahim M.M. et al. (2010). A novel agricultural waste adsorbent for the removal of lead (II) ions from aqueous solutions, Journal of Hazardous Materials, 182(1-3), 377-385.

Igunnu E.T. and Chen G.Z. (2012), Produced water treatment technologies, International Journal of Low-Carbon Technologies, 9, 157-177.

Jafer A.S, Hassan A.A. and Naeem Z.T. (2019). A study on the potential of moringa seeds in adsorption of organic content from water collected from oilfield refinery, Pakistan Journal of Biotechnology, 16(1).

Manilal A.M., Soloman P.A. and Ahmed Basha C. (2020). Removal of oil and grease from produced water using electrocoagulation, Journal of Hazardous, Toxic, and Radioactive Waste, 24(1),04019023.

Mousa K.M. and Taha A.H. (2015), Adsorption of reactive blue dye onto natural and modified wheat straw, Journal of Chemical Engineering and Process Technology, 6(6), 1000260.

Mukhtar A., Mellon N., Saqib S., Lee S.-P. and Bustam M.A. (2020). Extension of $\mathrm{BET}$ theory to $\mathrm{CO}_{2}$ adsorption isotherms for ultramicroporosity of covalent organic polymers, SN Applied Sciences, 2(7), 1-4.

Naeem H.T. and Hassan A.A. (2018), Effectiveness \& economy of sawdust wood adsorbents in removing anionic dyes of aqueous solutions, Pakistan Journal of Biotechnology, 15(2), 311-320.

Naeem H.T., Hassan A.A. and Al-khateeb R.T. (2018). Wastewater(Direct Red Dye) treatment-using solar fenton process, Journal of Pharmaceutical Sciences and Research (JPSR), 10(9), 2309-2313.

Namdeo M. (2018). Magnetite nanoparticles as effective adsorbent for water purification-a review, Advances in Recycling and Waste Management, 2(3), 1000135.

Naser G.F., Dakhil I.H., Ali A.H. and Taha A.H. (2021). Methylene violet dye adsorption using onion skins: kinetics and isotherm 
studies, IOP Conference Series: Materials Science and Engineering, 1090(1), 012047.

Ofomaja A.E., Naidoo E.B. and Modise S.J. (2009). Removal of copper (II) from aqueous solution by pine and base modified pine cone powder as bio sorbent, Journal of Hazardous Materials, 168, 909-917.

Pereira F.V., Gurgel L.V.A. and Gil L.F. (2010). Removal of $\mathrm{Zn}^{2+}$ from aqueous single metal solutions and electroplating wastewater with wood sawdust and sugarcane bagasse modified with EDTA dianhydride (EDTAD), Journal of Hazardous Materials, 176(1-3), 856-863.

Petrova T.M., Fachikov L. and Hristov J. (2011). The magnetite as adsorbent for some hazardous species from aqueous solutions: a review, International Review of Chemical Engineering (I.RE.CH.E.), 3(2).

Ramachandran P., Vairamuthu R. and Ponnusamy S. (2011), Adsorption isotherms, kinetics, thermodynamics and desorption studies of reactive orange 16 on activated carbon derived from Ananas Comosus (L.) Carbon, ARPN Journal of Engineering and Applied Sciences, 6(11), 15-26.

Rangabhashiyam S. and Selvaraju N. (2015), Efficacy of unmodified and chemically modified Swietenia mahagoni shells for the removal of hexavalent chromium from simulated wastewater, Journal of Molecular Liquids, 209, 487-497.

Rashid A.H., Hassan A.A., Hadi R.T. and Naje A.S. (2020). Treatment of oil content in oilfield produced water using chemically modified waste Sawdust as Biosorbent, EM International, 26(4), 1563-1571.

Rosenblum J.S., Sitterleya K.A., Thurman E.M., Ferrer I. and Linden K.G. (2016). Hydraulic fracturing wastewater treatment by coagulation-adsorption for removal of organic compounds and turbidity, Journal of Environmental Chemical Engineering, 4(2), 1978-1984.

Xu Z., Cai J. and Pan B. (2013), Mathematically modeling fixed-bed adsorption in aqueous systems, Journal of Zhejiang University Science A, 14, 155-176.

Zsirai T., Qiblawey H., Buzatu P., Al-Marri M. and Judd S.J. (2018). Cleaning of ceramic membranes for produced water filtration, Journal of Petroleum Science and Engineering, 166, 283-289. 